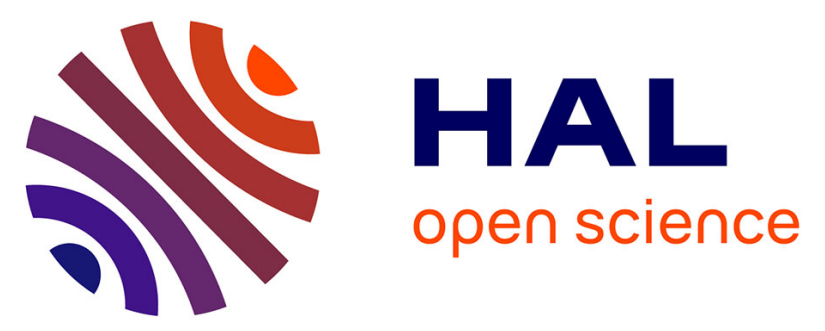

\title{
High flow nasal cannula: an alternative to continuous positive airway pressure in cats
}

Florent Baudin, Céline Pouzot-Nevoret, Leila Hocine, Bernard Allaouchiche

\section{To cite this version:}

Florent Baudin, Céline Pouzot-Nevoret, Leila Hocine, Bernard Allaouchiche. High flow nasal cannula: an alternative to continuous positive airway pressure in cats. Journal of Feline Medicine and Surgery, 2020, 23, pp.405 - 406. 10.1177/1098612x20977779 . hal-03257759v1

\section{HAL Id: hal-03257759}

\section{https://hal-vetagro-sup.archives-ouvertes.fr/hal-03257759v1}

Submitted on 11 Jun 2021 (v1), last revised 16 Jul 2021 (v2)

HAL is a multi-disciplinary open access archive for the deposit and dissemination of scientific research documents, whether they are published or not. The documents may come from teaching and research institutions in France or abroad, or from public or private research centers.
L'archive ouverte pluridisciplinaire HAL, est destinée au dépôt et à la diffusion de documents scientifiques de niveau recherche, publiés ou non, émanant des établissements d'enseignement et de recherche français ou étrangers, des laboratoires publics ou privés. 


\section{High flow nasal cannula: an} alternative to continuous positive airway pressure in cats
$1-2$

(C) The Author(s) 2020

Article reuse guidelines:

sagepub.com/journals-permissions

DOI: 10.1177/1098612X20977779 journals.sagepub.com/home/jfm

This letter was handled and processed by the European Editorial Office (ISFM) for publication in JFMS

(S)AGE

\section{Dear Editors,}

We read with great interest the study by Di Bella et al recently published in JFMS, which describes the use of continuous positive airway pressure (CPAP) by a helmet in healthy cats under general anaesthesia. ${ }^{1}$ We agree with the authors that non-invasive ventilation is useful to prevent and treat respiratory dysfunctions in animals. Di Bella et al provided encouraging results on the use of CPAP in cats. However, the equipment used to deliver CPAP with a helmet interface was complex and evaluated on cats under general anaesthesia, raising questions on the safety of its use in cats with respiratory failure.

High flow nasal cannula (HFNC) therapy is increasingly used in human medicine, especially in infants, and it is trending towards replacing nasal CPAP as primary support in mild to moderate respiratory failure. ${ }^{2}$ HFNC is a device that allows the delivery of a humidified and heated gas with a higher flow than the inspiratory flow of the patient. ${ }^{3}$ This technique presents several physiological benefits. It provides an oxygen reserve by making a washout of the pharyngeal cavity, and it can deliver a positive expiratory pressure (PEP) (Figure 1). In preterm infants, the level of PEP was estimated to be between 2 and $6 \mathrm{cmH}_{2} \mathrm{O}$ depending on the flow rate. ${ }^{4}$ In dogs, Jagodich et $\mathrm{al}^{5}$ showed that a CPAP level of around $5 \mathrm{cmH}_{2} \mathrm{O}$ was achieved by HFNC at a flow rate of $21 / \mathrm{kg} / \mathrm{min}$, with an improvement in oxygenation. These CPAP levels are in the same range as those used by Di Bella et al. ${ }^{1}$ We have been using this as a primary respiratory support device for acute respiratory failure in both dogs and cats for 2 years in our intensive care unit. In a pilot study, we demonstrated that HFNC improves oxygenation parameters and is well tolerated in dyspnoeic dogs. ${ }^{6}$ Our initial experiences in cats show that adequate placement of the nasal cannula does require sedation, but this technique is then well tolerated by the cat and does not necessitate further heavy sedation. Although these findings need to be confirmed by prospective studies, HFNC appears to be an interesting alternative to CPAP delivered by a helmet as it is usable in awake animals and does not limit access to the upper airway during respiratory support (Figure 1).

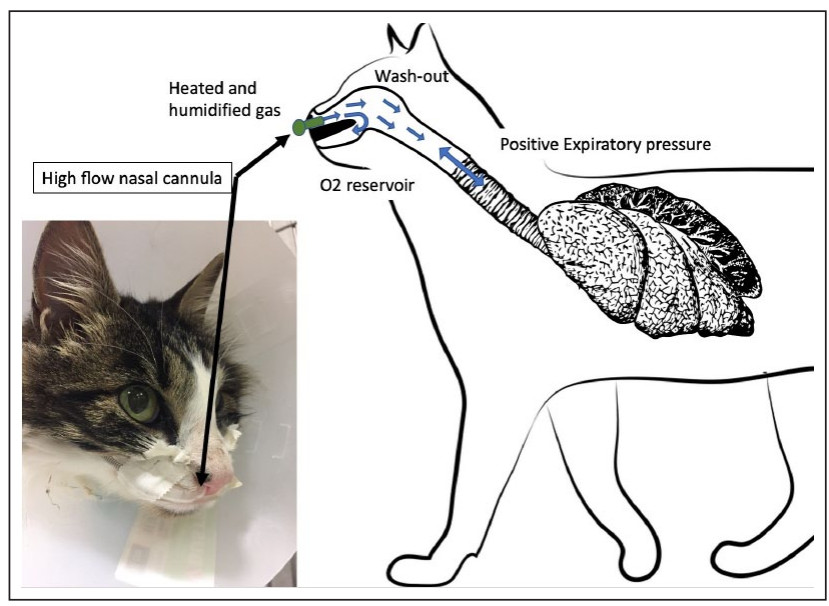

Figure 1 Physiological effect of high flow nasal cannula and an example of its use in a cat with moderate respiratory failure due to cardiogenic pulmonary oedema

\section{Florent Baudin ${ }^{1,2}$ \\ Céline Pouzot-Nevoret ${ }^{2,3}$ Leila Hocine ${ }^{2,3}$ \\ Bernard Allaouchiche ${ }^{2,4}$ \\ 1Service de réanimation pédiatrique, Hospices Civils de Lyon, Hôpital Femme Mère Enfant, France ${ }^{2}$ Agressions Pulmonaires et Circulatoires dans le Sepsis (APCSe), VetAgro Sup, Université de Lyon, France \\ 3Intensive Care Unit (SIAMU), \\ VetAgro Sup, Université de Lyon, France 4Service de Réanimation, Hospices Civils de Lyon, \\ Centre Hospitalier Lyon-Sud, France}

Conflict of interest The authors declared no potential conflicts of interest with respect to the research, authorship, and/or publication of this letter.

Funding The authors received no financial support for the research, authorship, and/or publication of this letter. 
Ethical approval This work did not involve the use of animals and therefore ethical approval was not specifically required for publication in JFMS.

Informed consent This work did not involve the use of animals and therefore informed consent was not required. No animals or humans are identifiable within this publication, and therefore additional informed consent for publication was not required.

The corresponding author responds:

Thank you for your interest in and comments on our study, which aimed to document the physiological effects of CPAP applied with a helmet in cats under general anaesthesia, and to evaluate also its feasibility and safety. ${ }^{1}$ Any extrapolation of our findings to cases of respiratory failure is purely speculative, since this case scenario has not been evaluated in our study. The helmet interface requires specific knowledge of the equipment (similarly to HFNC) but it is simple and safe to use.

HFNC therapy provides oxygen and respiratory support, and has recently been validated in dogs.5,6 The high flow of fresh gas delivered into the upper airway of the patients provides $\mathrm{O}_{2}$, promotes the washout of $\mathrm{CO}_{2}$ (reduction of dead space) and creates a resistive effect on the expiratory flow of the patient, which generates a moderate 'CPAP effect' $\left(4-6 \mathrm{cmH}_{2} \mathrm{O}\right) .{ }^{7}$ The level of CPAP generated by the HFNC depends on several factors including the delivered gas flow, and the patient's breathing pattern and anatomical characteristics. ${ }^{7}$ It is variable and not adjustable by the operator. For instance, open-mouth breathing has been proven to significantly reduce the CPAP effect in human studies, and this could be a critical aspect in dogs and cats. ${ }^{8}$ In contrast, helmet CPAP is able to deliver a fixed level of pressure support that the operator can adjust based on the requirements of the patient, independently from the anatomical conformation and individual anatomical variability. ${ }^{9} \mathrm{~A}$ recent study in dogs showed that $5 \mathrm{cmH}_{2} \mathrm{O}$ of CPAP is able to increase the volume of the laryngeal area by more than $50 \% .{ }^{10}$

In our study, CPAP was administered with an $\mathrm{FiO}_{2}$ of 0.21 in order to investigate the pure effects of the pressure support on gas exchange. ${ }^{1}$ HFNC is an innovative and interesting technique that we believe can have several applications in veterinary patients. In dogs it appears to work very well, but our own experience in cats suggests that there are some limitations in terms of interface adaptation to the anatomical characteristics of the species. We are pleased to read that you report a positive experience with HFNC in cats, in terms of improvement in oxygenation, and we are looking forward to seeing your data shared with the scientific community. However, we would like to add that in order to investigate the poor effect of the pressure support (CPAP), the HFNC should be tested with air, like we did in our study with the helmet. ${ }^{1}$

Francesco Staffieri

Section of Veterinary Clinics and Animal Production, Department of Emergency and Organs Transplantation, University of Bari 'Aldo Moro', Italy

\section{References}

1 Di Bella C, Araos J, Lacitignola L, et al. Effects of continuous positive airway pressure administered by a helmet in cats under general anaesthesia. J Feline Med Surg. Epub ahead of print 25 August 2020. DOI: 10.1177/1098612X2095127.

2 Cambonie G, Pons-Odena M, Baleine J, et al. High flow nasal cannulae for acute viral bronchiolitis in young infants: evidence-based medicine is underway to define target populations and optimal flows. J Thorac Dis 2017; 9: 1763-1766.

3 Dysart K, Miller TL, Wolfson MR, et al. Research in high flow therapy: mechanisms of action. Resp Med 2009; 103: 1400-1405.

4 Liew Z, Fenton AC, Harigopal S, et al. Physiological effects of high-flow nasal cannula therapy in preterm infants. Arch Dis Child Fetal Neonatal Ed 2020; 105: 87-93.

5 Jagodich TA, Bersenas AME, Bateman SW, et al. Comparison of high flow nasal cannula oxygen administration to traditional nasal cannula oxygen therapy in healthy dogs. J Vet Emerg Crit Care (San Antonio) 2019; 29: 246-255.

6 Pouzot-Nevoret C, Hocine L, Nègre J, et al. Prospective pilot study for evaluation of high-flow oxygen therapy in dyspnoeic dogs: the HOT-DOG study. J Small Anim Pract 2019; 60: 656-662.

7 Di Mussi R, Spadaro S, Stripoli T, et al. High-flow nasal cannula oxygen therapy decreases post extubation neuroventilatory drive and work of breathing in patients with chronic obstructive pulmonary disease. Crit Care 2018; 22: 180. DOI: 10.1186/s13054-018-2107-9.

8 Parke RL and McGuinness SP. Pressures delivered by nasal high flow oxygen during all phases of the respiratory cycle. Respir Care 2013; 58: 1621-1624.

9 Staffieri F, Crovace A, De Monte V, et al. Noninvasive continuous positive airway pressure delivered using a pediatric helmet in dogs recovering from general anesthesia. J Vet Emerg Crit Care 2014; 24: 578-585.

10 Rondelli V, Guarracino A, Iacobellis P, et al. Evaluation of the effects of helmet continuous positive airway pressure on laryngeal size in dogs anesthetized with propofol and fentanyl using computed tomography. J Vet Emerg Crit Care 2020; 30: 543-549. 